\title{
COTTON ACREAGE REDUCTION AND THE TENANT FARMER
}

\author{
PAUL W. BRUTON*
}

$x$

It was natural that the Agricultural Adjustment Administration which was created "to relieve the existing national economic emergency by increasing agricultural purchasing power" should have turned its attention at the earliest possible moment to the control of cotton prduction. In no section of the country had purchasing power sunk to such disastrously low levels as it had in the Cotton Belt. Over a period of years, the World War, the boll weevil, and the depression had thrown cotton production so out of line with consumption that in $193^{2}$ the supply of American cotton was practically double the amount which could find a market. The existence of such a surplus had its inevitable effect upon the price level, which since 1923 had fallen from 29 cents a pound to $61 / 2$ cents. The plight of the cotton farmer was aggravated further by the fact that there were no other staple crops which he was capable of producing on a commercial basis, and the southern farming population was being swelled constantly by the return of families from the overcrowded industrial centers where they had sought their fortunes during the halcyon days of the industrial boom.

In the spring of 1933 it was clear that immediate action of a rather far-reaching kind had to be taken if southern agriculture was to be saved from one of the most serious crises of its history. Such action was authorized by the Agricultural Adjustment Act, ${ }^{1}$ which provides for the reduction in acreage or production of designated "basic" agricultural commodities." On May 23, eleven days after the President had

- A.B., 1929, LL.B., 1929, University of California; J.S.D., 1930, Yale. Associate Professor of Law, Duke University School of Law. Member of the California Bar. Contributor to legal peribdicals.

${ }^{1}$ Act of May 12, I933, 48 STAT. 31, 7 U. S. C. A. (Supp.) c. 26.

2 "The Congress of the United States declared in section 2 of the Agricultural Adjustment Act that its policy is to establish and maintain such balance between the production and consumption of agricultural commodities and such marketing conditions therefor, as will reëstablish prices to farmers at a level that will give agricultural commodities a purchasing power with respect to articles that farmers buy, equivalent to the purchasing power of agricultural commodities in the base period. The base period in the case of all agricultural commodities except tobacco is the pre-war period, August Igog to July IgI4. In the case of tobacco the base period is the post-war period, August Igrg to July I929. . . . Roughly, the principal powers granted by Congress to effectuate the purposes of the act fall into two groups-those dealing with production control and benefit contracts and those dealing with marketing agreements and licenses. .. . Under the act, benefit payments may be made to the producers of seven 'basic agricultural commodities.' These are wheat, cotton, corn, hogs, rice, tobacco, and milk and its products. They are listed as basic for 
signed the Act, a conference was called in Washington to formulate the r933 agricultural adjustment program for cotton. The Act authorizes the reduction in either acreage or production, but the conference, composed of representatives of the Bureau of Agricultural Economics, the Extension Service, and the Agricultural Adjustment Administration (AAA), decided that while fluctuating yield was an important element in cotton production, acreage was the vital factor, and acreage reduction, rather than a more direct means of production control, should be the goal of the program.

The Act provides for reduction in acreage or production by means of agreements with producers or "by other voluntary methods," and authorizes the Secretary of Agriculture to make rental or benefit payments in such amounts as he deems fair and reasonable. ${ }^{3}$ At the conference it was determined that the Secretary should immediately enter into acreage reduction contracts with cotton producers, and the elimination of ro,000,000 acres or about 3,000,000 bales of cotton from the current crop was fixed as the objective for 1933 .

The plan was announced June 19, and the Extension Service of the Department of Agriculture was called upon to direct the work in the field, which included the dissemination of information, the execution of the various documents composing the contract, and a check-up on the crop taken out of production. In each county the

several reasons. One is that changes in their price strongly influence changes in the prices of other agricultural commodities. Another is that the United States produces an exportable surplus of nearly all of them. Export demand and world price of each had fallen sharply before the act was passed, and these commodities were generally in a relatively worse economic situation than others that are produced and consumed on a domestic basis. A third reason is that each of these commodities is put through some manufacturing process before it is ready for human consumption and their production and distribution can be more easily regulated in these processing channels than could the production and distribution of commodities not so processed. . . .

"The second group of powers contained in the act is also directed toward giving the producer of agricultural commodities more nearly his fair share of the national income. These powers are conferred by the marketing agreement section of the act and relate to trade practices among processors and distributors of farm products. They make the Government both an arbiter and a partner in agreements among associations of producers, processors, and distributors of farm goods. Like the benefit contracts, these powers are designed to assist in restoring parity prices to farmers while protecting the consumer from unfair increases in his costs.

"Powers under the marketing agreement section are not limited to the seven basic commodities as in the case of production control powers but may be applied to all agricultural produce. Furthermore, agrecments may extend from the producer to the consumer and may touch every point in the chain of distribution." Agricultural Adjustment, A Report of Administration of the Agriculturat Adjustment Act, May 1933 to February 1934, Pp. 4-6.

Since the above was written the act has been amended to include sugar beets and sugareane as basic commodities. Act of May 9, 1934, Public, No. 213, 73rd Cong. 2nd Sess.

section 8 ( $r$ ) reads in part as follows: In order to effectuate the declared policy, the Secretary of Agriculture shall have power-

(x) To provide for the reduction in the acreage or reduction in the production for market, or both, of any basic agricultural commodity, through agreements with producers or by other voluntary methods, and to provide for rental or benefit payments in conncction therewith or upon that part of the production of any basic agricultural commodity required for domestic consumption, in such amounts as the Secretary deems fair and reasonable, to be paid out of any moneys available for such payments." 
campaign was carried on under the direction of the County Agricultural Extension Agent who is the permanent local representative of the Extension Service."

The first document which the farmer was asked to sign was an offer to enter into a contract with the Secretary of Agriculture. In it the farmer described the location of his farm and stated the number of acres he had planted to cotton and whether the stand was good, fair, or poor. He was also required to state the amount of fertilizer he had used and to give the I932 yield of his land, as well as to estimate the pounds per acre which he might reasonably expect to harvest during $1933 .{ }^{\circ}$ He then stated the number of acres of cotton which he offered to the Secretary and which he agreed to take out of production in accordance with such regulations as might thereafter be prescribed. He stated that the cotton thus offered to the Secretary represented a fair average of his crop. Ordinarily producers were not permitted to take out of production less than 25 per cent nor more than $5^{\circ}$ per cent of their land planted to cotton. This offer became a binding contract upon acceptance by the Secretary, and the cotton taken out of production was plowed under or destroyed in some other approved manner. The producer was then required to sign a certificate of performance in which he certified that he had completely destroyed in the manner prescribed by the county agent all the crop of cotton on the land embraced in his offer, and certified further that he had performed all other terms and conditions of his contract. ${ }^{8}$

In order to induce farmers to enter into such a contract and plow up their growing cotton it was thoúght necessary to have the benefit payments approximate \$II per acre on the average, the amount in each case to depend upon the average yield of the land taken out of production. ${ }^{7}$ The producer was given a choice between taking his payments all in cash, or part in cash and part in the form of an option

"The county agent was assisted by a "County Committec" chosen from among the cotton growers in the county. In addition, "Local Committees" were created to work in the various localities throughout the county. They interviewed producers individually, held meetings to explain the program, and assisted in directing the execution of the contracts. Local committees were instructed that one member of the committee should visit and personally inspect each farm in the locality offered for acreage reduction. No contracts were accepted without the approval of the local committee which was indicated by the members of the committee placing their signatures upon the form containing the farmer's offer to reduce acreage.

E The producer also agreed not to use more fertilizer per acre on the acreage remaining in cotton than was used in 1932 unless such application had been made prior to the signing of the offer. The member of the local committee who inspected the farm was required to subscribe to the following statement: "The undersigned authority has inspected the land embraced in the foregoing offer, concurs in the estimate of probable production thereon, certifies after investigation that the facts stated therein are to the best of his knowledge and belief correct, and witnesses the signature of the producer."

"The members of the county committee and the local committee were also required to certify that they approved or refused to approve the producer's certificate of performance.

Approximately 40 to 45 per cent of the cotton crop enters domestic consumption and the funds with which to make benefit payments were obtained from a processing tax of 4.2 cents a pound on all cotton domestically consumed. The schedule of payments when compensation was made in cash only was as follows:

Estimated yicld per acre for 1933 on land to be taken out of production

Payment per acre

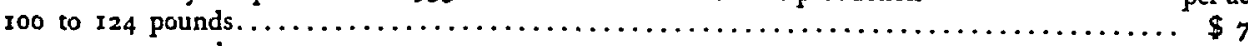

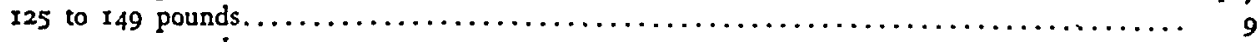

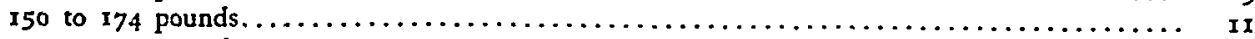

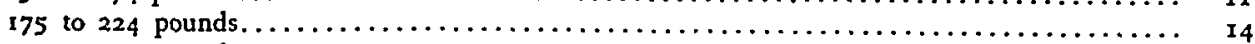

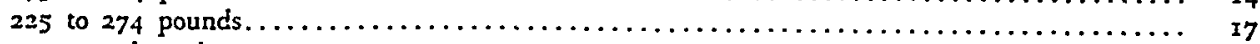

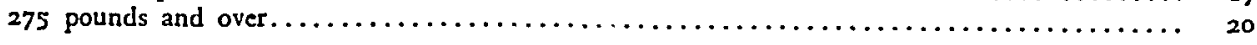


on cotton held by the Government. 8 He was required to state in his offer which plan of payment he desired.

The option plan deserves brief description as it was an important part of the program to reduce the cotton surplus. The Federal Farm Board, in its attempt to stabilize farm prices, had acquired an interest in a large amount of cotton. Pursuant to the Agricultural Adjustment Act, an agreement was reached June 7 between the Secretary of Agriculture and the Farm Credit Administration by which this cotton, amounting to some $2,487,300$ bales, ${ }^{9}$ was transferred to the Secretary and made available for use in the acreage reduction program. A producer who chose to participate in the option plan received a cash payment plus an option on a certain number of bales of the cotton held by the Secretary, the number of bales optioned being equal to the estimated yield of the land taken out of production by the producer. The option contract nominally gave the producer the right to buy the cotton at 6 cents a pound, but actually no cotton was ever delivered to him. When he gave the Secretary notice that he exercised his option the cotton was sold on the market, and he was paid anything above 6 cents that it might bring. ${ }^{10}$ If the sale was made for less than 6 cents he suffered no loss. While the producer was not guaranteed a profit on his option, his chances of realizing one were very good, for the price of cotton would surely go considerably above 6 cents a pound if the program had anything like the expected effect on the market. ${ }^{11}$ Of the $1,026,5^{1} 4$ offers accepted by the Secretary,

${ }^{3}$ The schedule of cash payments made under the cash-plus-option plan was as follows:

Estimated yield per acre for 1933 on land to be taken out of production I00 to 124 pounds.

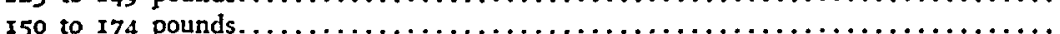

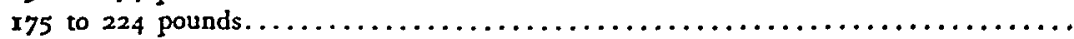

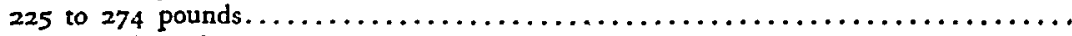

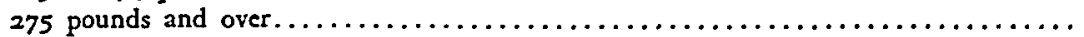

For an estimate of total benefits received under the cash-plus-option plan see note 12, infra.

Cash payment per acre plus option

$\$ 6$

7

10

11

12

This cotton consisted of some 455,200 bales represented by future contracts on the New York Cotton Exchange, I,128,774 bales acquired from the American Cotton Coöperative Association, and 788,000 bales pledged by producers to the Secretary to secure loans made by the Secretary during several years preceding 1933. Jurisdiction over this pledged cotton passed from the Secretary to the Farm Credit Administration by executive order dated May 27 which directed the latter to reduce the cotton to possession.

${ }^{10}$ The option contract provided that it was non-transferable and that it expired May I, 1934, unless exercised before that date. However, producers have been given the opportunity to extend their options to May I, 1935, provided that the option holder is required to pay the carrying charges after May I, 1934, which amount to about 40 cents per bale per month.

${ }^{11}$ New York Cotton Exchange quotations for spot cotton June 30, 1933, to May 31, 1934, were as follows:

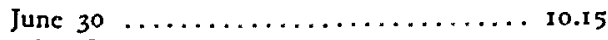

July $18 \ldots \ldots \ldots \ldots \ldots \ldots \ldots \ldots \ldots$ Ir.75

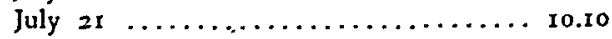

Aug. $1 \ldots \ldots \ldots \ldots \ldots \ldots \ldots \ldots \ldots$ 10.40

Aug. $16 \ldots \ldots \ldots \ldots \ldots \ldots \ldots \ldots \ldots . \ldots .65$

Aug. $17 \ldots \ldots \ldots \ldots \ldots \ldots \ldots \ldots . .6 .30$

Sept. $5 \ldots \ldots \ldots \ldots \ldots \ldots \ldots \ldots \ldots \ldots .9 .10$

Sept. $19 \ldots \ldots \ldots \ldots \ldots \ldots \ldots \ldots \ldots \ldots$ r 0.45

Sept. $30 \ldots \ldots \ldots \ldots \ldots \ldots \ldots \ldots \ldots . \quad 9.95$

Oct. $77 \ldots \ldots \ldots \ldots \ldots \ldots \ldots \ldots \ldots . \ldots .45$

Bank and Quotation Record, William Dana Co., New York City.

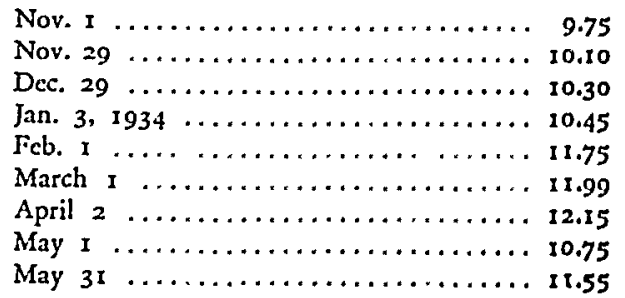

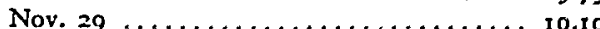

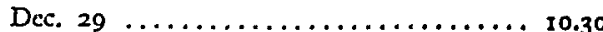

Jan. 3, $1934 \ldots \ldots \ldots \ldots \ldots \ldots \ldots \ldots . \ldots \ldots . \ldots 10.45$

$\ldots \ldots .11 .75$

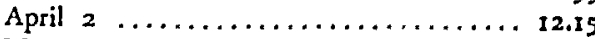

May $1 \ldots \ldots \ldots \ldots \ldots \ldots \ldots \ldots \ldots \ldots \ldots . \ldots \ldots 10.75$

May $31 \ldots \ldots \ldots \ldots \ldots \ldots \ldots \ldots \ldots \ldots \ldots$ It.55 
571,969 or 55.7 per cent called for cash benefits plus options. To meet this demand $2,387,795$ bales of cotton were optioned.

Although the cash-plus-option plan offered the producer the reasonable prospect of a greater total benefit than the straight cash plan, ${ }^{12}$ it postponed a large part of his benefit payments until his optioned cotton could be sold at a worthwhile profit. In order to enable the producer to secure an advance on his option a supplementary plan was devised by which he was given the opportunity to enter into what was called "Exercise of Cotton Option and Pool Agreement."13 By this agreement the Secretary "sold" the optioned cotton tc the producer, who directed that it should be delivered to the Cotton Pool which had been created by the AAA to facilitate the handling of the government-owned cotton. The manager of the pool was authorized to borrow from the Commodity Credit Corporation 4 cents a pound on the cotton covered by the option, and the money when obtained was advanced to the producer, who also received a participation trust certificate in the pool. ${ }^{14}$ The manager might sell the cotton in the pool any time it could be marketed on the basis of 15 cents per pound, middling $7 / 8$-inch, but after July $3 \mathrm{I}$, 1934, the Secretary might, in his discretion, dispose of all or any part of the cotton irrespective of the price. By means of these pool agreements farmers have been able to secure advances of 4 cents a pound on their optioned cotton and at the same time have the right to receive additional payments if the cotton is eventually sold for more than ro cents a pound.

21 The following schedule gives an estimate of total benefits received under the cash-plus-option plan, assuming that the optioned cotton was sold at 10 cents per pound.

Approximate number of pounds of lint cotton optioned per acre

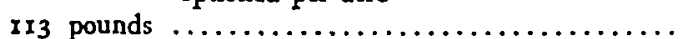

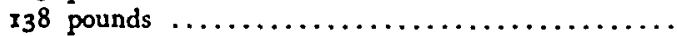

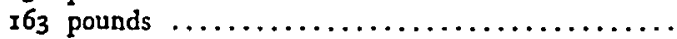

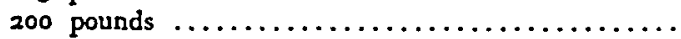

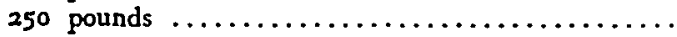

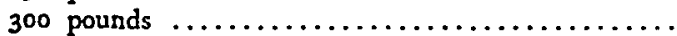

12 When it became apparent that the 1933 crop would exceed expectations an attempt was made to protect the price of cotton by lending producers ro cents a pound on the unsold portion of their crop. These loans were not limited to producers who had signed 1933 contracts, and in order that those who had participated in the program and taken options might be placed on a parity with the producers who had not signed contracts, the plan for advancing 4 cents a pound against the optioned cotton was devised.

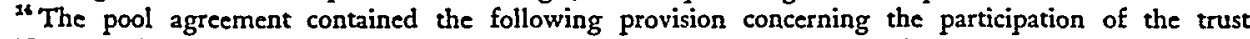
certificate holders in the profits of the pool: "The manager after paying all charges incident to the operation of the pool shall pay to the Secretary the proceeds derived from the sale of any cotton marketed by the pool pursuant hereto up to an amount equal to 6 cents per pound of such cotton plus such interest as may have become due subsequent to the date of the delivery by the Secretary to the pool of such cotton on any loans (including any renewals thereof) made to the Secretary to finance the acquisition and/or carrying of such cotton. All such proceeds remaining after payment as above to the Secretary shall be paid to the Commodity Credit Corporation up to the amount of the loans hereby authorized to be made from said corporation on such cotton, together with all interest due on such loans. After all debts and liens against the cotton shall have been discharged and all expenses incurred in carrying, handling, and/or marketing of said cotton, and in the conduct of the pool have been paid, the manager shall thereafter distribute the remaining proceeds ratably to the holders of record of Participation Trust Certificates herein provided for in accordance with their several interests as established by said certificates." 
II

One of the most difficult problems in the cotton adjustment program has been the proper distribution of benefits among the various persons-landlords, tenants, and creditors-who may be interested in the cotton growing or to be grown on the land taken out of production. In seeking to improve the plight of southern agriculture through the distribution of these payments the AAA encountered the South's unsolved problem of farm tenancy. The effect of the cotton program upon this underlying social problem merits extended consideration calling for an analysis of the relevant provisions of the acreage reduction contracts, the regulations issued in connection therewith, and their application in the light of the legal and economic organization of agriculture in the cotton belt.

The problem of distribution was complicated in 1933 by the fact that the crop had already been planted and in many cases special interests, such as crop liens, had been created before the acreage reduction contract was signed. Thus there might be a number of persons who were so interested in the crop that it was necessary to make them parties to the contract or to secure their written consent in some manner. Accordingly it was arranged that the contract should be signed by a primary contracting party, referred to as the producer, who agreed to secure the written consent of certain other persons interested in the crop. Whether a person signed as producer or as a consenting party was of considerable practical importance in the distribution of benefits. Both cash benefit and option checks were made payable solely to the producer unless there was a request from him in proper form that they be made payable to some other party. This practice was very strictly followed, especially in the case of option checks.

The party signing as producer was also in a very advantageous position because the consenting parties might neglect to see that any request was made as to payment. This was very likely to happen when they were not in an equal bargaining position with him. Furthermore, since the producer was relied upon to obtain the consent of other interested parties, these might be left off entirely if he did not choose to notify them and failed to report the true situation to the county agent.

Upon the question of what persons were qualified or required to sign as producer, or as consenting parties, the contract was singularly vague. According to the offer form, the person signing as producer was one who owned and operated, or rented and operated, the farm covered by the contract. This excluded from the rôle of principal contracting party the creditor who neither owned nor rented the farm although he might hold a crop lien for more than the value of the crop. ${ }^{15}$ However, it left the matter open as between landlords and tenants, and the field workers were instructed that the person having legal ownership of the crop was to be regarded as

\footnotetext{
25 This was a sound scsult. for the agricultural .eljustment program has been undertaken for the benefit of persons engaged in farming. and not for the benefit of creditors of farmers, except insofar as an increased return to farmers will bentfit such creditors.
} 
the proper party to sign the offer as producer. As will be seen later this hardly contributed to a clarification of the situation.

It proved to be equally difficult to determine just what persons were required to be included as consenting parties. In Paragraph 3 of the offer, the party signing as producer was required to list all lien-holders, and in Paragraph 4 he agreed that "consent in writing of the lien-holders has been or will be obtained by me before any part of the cotton planted is taken out of production and/or before receipt by me of any benefit which may accrue to me hereunder." These two paragraphs require the party signing as producer to list all lien-holders and secure their written consent, but nothing is said about other parties who may be interested in the crop, and this created difficulties in many situations. For instance, if a landlord and tenant are farming on shares in a state where the tenant is not a lien-holder but a part owner of the crop, could the landlord legally enter into the contract without notifying the Secretary that he had a tenant and without securing the tenant's consent? Apparently he could as far as the provisions discussed above are concerned.

In Paragraph 5 of the offer the producer promised that if the offer was accepted he would conform to such regulations as might be prescribed by the Secretary or authorized by him pertaining to the purposes of the offer. It may be questioned how far this provision would permit the Secretary to go in altering the obligations of the contract as contained in the offer, but probably a regulation which would impose an obligation on the producer to secure the consent of all persons interested in the crop, whether lien-holders or not, would not be regarded as going too far. On July 25 , six days after the sign-up campaign closed, regulations were approved and published which did broaden the producer's obligation in this respect. "Producer" was defined as an "operator" and then followed this provision: "Sec. 200. Any producer, as defined above, who owns or rents cotton lands and has or will have legal ownership of the cotton crop produced in the year 1933 on such land is eligible to become a party to a cotton contract with the Secretary. Where ownership is in more than one persan, all who are interested as owners must sign the offer either as principal parties or as consenting parties." One is entitled to suppose "must" here would be construed to mean that the person signing the contract as producer would commit a breach of contract if he did not secure the consent of other parties as required by this regulation. If this be true, the landlord signing a contract was under an obligation to secure the consent of his share-tenant if the tenant was a lien-holder, or if he could be said to have "legal ownership" of the crop; otherwise his consent was not required. ${ }^{18}$

Section 300 of the Regulations used a little different language. There it was provided: "If the producer does not obtain the consent and signature of all lien-holders and/or other persons having an interest in the crop on the acreage to be withdrawn from production, and the Secretary enters into a cotton contract with the producer

${ }^{10}$ Field workers were instructed that it was "necessary that all lien-holders and/or other persons having an interest in the 1933 cotton crop" should sign as consenting parties. 
with or without knowledge of the lack of consent of such interested party or parties, the Secretary shall have the right at any time to withdraw from such contract, or to withhold benefit payments until the consent of all such interested parties has been obtained or the matter has been otherwise adjusted."17 Possibly the phrase "persons having an interest in the crop" means "persons interested as owners" referred to in Section 200 quoted above. At any rate this much is clear-persons interested in the crop as part owners or lien-holders should have signed the contract either as principal parties or consenting parties, and their right to sign as principal parties should probably have depended upon whether they exercised sufficient control over the working of the crop to be called "operators."

\section{III}

One can secure some idea of how these provisions worked out in practice only by having in mind a general outline of the landlord and tenant system which exists in the Southern states. Tenantry in the South, which is vastly different from what it is in other parts of the country, had its origin in the adjustments made necessary by the Civil War and the abolition of slavery. Before and after emancipation the Negro constituted, as he still does in many of the Southern states, the chief or almost exclusive source of agricultural labor. The plantation system, always the heart of cotton culture, was as fully dependent on black labor during the Reconstruction Period as it had been in the ante bellum days. On the other hand, the Negro, although legally free, possessed none of the resources which make economic freedom possible and was totally dependent upon his former masters for whatever living he might obtain. The result was the "share-cropper" system, by which most of the cotton in this county is still grown. Under this system as it usually exists, the landowner supplies the land, the seed, the farm equipment, and living quarters for the cropper and his family, while the cropper furnishes the labor only. Each party receives as compensation a one-half share of the crop. However, the cropper rarely ever receives his share in specie or in cash, for during the time he is working the crop he is dependent upon his landlord to "furnish" him food and the necessaries of life, the costs of which, plus "carrying" and "interest" charges, ${ }^{18}$ are deducted from his share ${ }^{19}$ of the crop. Sometimes these supplies are obtained at the plantation

${ }^{17}$ Section 205 of the Regulations required each consenting lien-holder and each other interested person to indicate his consent by signing the offer as an "interested party." Section 206 provided that, on request, checks might be made payable to producers and lien-holders jointly. Provision was also made for joint payment where crops were in the joint ownership of partnerships, husbands and wives, or producers signing as joint operators.

${ }_{18}$ On the average the landlord's advances to the tenant are for a period of three or four months. It is quite usual for the charges to amount to 40 or 60 per cent when computed on a per annum basis. In many instances these charges are not bona fide interest and carrying charges but are a means of diverting a larger share of the crop to the landlord.

${ }^{20}$ Statutes give the landlord a lien on the crop for the advances made to the tenant. Arr. Dig. STAT. (Crawford \& Moses, 192I), \$6890; GA. ANN. COde (Michic, I926) \$3348; Miss. Code ANN. (1930) $\$ \$ 2186,2238$; N. C. CODE (Michie, r93I) \$2355; S. C. CODE (I932) \$\$877I, 8779; TENN. CODE (Williams, Shannon, Harsh, I932) 58018; TEX. STAT. (1928) art. 5222. A statute in North Carolina provides that if a charge is made of more than ro per cent of the retail price of the supplies furnished, the crop lien shall be void as to the supplies for which such a charge is made. N. C. CoDE (Michie, I931) \$2482. 
commissary and at other times at a local store where the landlord stands good for the payment of the purchase price. Frequently at the end of the cropping season the cropper finds that the charges for his "furnish" have more than eaten up any proceeds he was entitled to. Thus he enters the next season without cash or capital of any kind and indebted to his landlord for past advances. ${ }^{20}$ And so the cycle goes on from one year to the next.

While share-cropping may be the most common form of cotton tenancy, there are many variations from it. The other type which is met with most frequently is that of the share-tenant or third-and-fourth renter, called such because the landlord receives as rent one-fourth of the cotton and one-third of the corn. The third-andfourth renter receives a larger share of the crop than the cropper because he supplies his own team and equipment. However it is not uncommon for him to be "furnished" just as the cropper is. Much less common than either the cropper or the third-and-fourth renter is the cash-tenant who pays a fixed cash rent and is usually an independent farmer much like most of the agricultural tenants in the northern and western states. Of course these three types of tenancy do not exhaust the forms of tenure existing in the Cotton Belt, and the frequency with which each is found differs with the state and locality, but they are sufficiently standard to illustrate the landlord and tenant problems which are presented by the acreage reduction program. $^{21}$

With the 1933 acreage reduction contract drawn as it was, it became important to ascertain what interests in the cotton crop were held by landlords and what by tenants under the different types of tenancy. An examination of the decisions and statutes of the various cotton states reveals that there is considerable difference in the legal terminology which is applied to landlords' and tenants' interests, although in practice they may be substantially the same throughout the South. If the tenant is given the "possession" of the land, legal ownership of the crop is in him unless the parties "intend" otherwise. 2 " The facts upon which the application of such a rule depend are so nebulous as to leave the matter open in most cases for the courts to decide as they think the practical considerations of the case dictate, and lien statutes frequently prevent the question from assuming any great importance. If title is in the tenant, a statute usually gives the landlord a lien for his rent whether it is in the form of cash or a share of the crop; if title is in the landlord the tenant will have a statutory lien for his share; and if the parties are regarded as tenants in common each is protected without a lien. It is interesting to note how these different means

\footnotetext{
s When a cropper or tenant moves from one farm to another his debt to his old landlord is frequently transferred to his new one. Such a system prevents tenants from avoiding payment of their debts by moving from farm to farm.

${ }^{2}$ For a further discussion of the various types of farm tenancies in the South, see Vance, Human Factors in the South's Agricultural Readjustment, stipra at p. 266 et seq.

${ }^{20}$ Birmingham v. Rogers, 46 Ark. 254 (1885); Hardeman v. Arthurs, 144 Ark. 289, 222 S. W. 20 (1920); Souter v. Cravy, 29 Ga. App. 557, 116 S. E. 231 (1923); Carpenter v. Strickland, 20 S. C. x (1883); Brock v. Halcy \& Co., 88 S. C. 373,70 S. E. Iori (IgII); Brown v. Johnson, I 8 Tex. 143, 12 S. W. (2d) 543 (1929).
} 
of giving the parties security in the crop have been applied in the share-cropping system. In Texas ${ }^{23}$ and possibly Arkansas ${ }^{24}$ and Mississippi ${ }^{26}$ the cropper and his landlord are tenants in common in the crop to the extent of their respective shares. In Alabama ${ }^{26}$ an act of 1923 vests title to the whole crop in the cropper, subject to a landlord's lien for his share. In Georgia, ${ }^{27}$ South Carolina, ${ }^{28}$ and North Carolina, ${ }^{20}$ title to the whole crop is vested in the landlord with a lien in the cropper for his share. Thus in all the important cotton states the cropper and a fortiori the thirdand-fourth tenant are interested in the crop at least to the extent of being either lien-holders or part owners.

According to the regulations and instructions issued by the AAA the contract might be signed by any "producer" who owned or rented cotton lands and had or would have legal ownership of the crop. Any attempt to apply this instruction strictly would have given rise to a great deal of difficulty. In many cases it could not readily be ascertained whether "legal ownership" was in the landlord or tenant, and if it was ascertained to be in one or the other the further question would arise as to whether that party "operated" the farm so that he could be called the "producer." As a matter of fact the county agent probably signed up the persons whom he regarded as being in actual control of the farm. When the land was rented for cash it was usually the tenant, and when the crop was worked by share-croppers it was nearly always the landlord. In the case of the third-and-fourth renter sometimes one and sometimes the other qualified, but when there was a dispute the landlord probably had his way because of his superior bargaining power.

In most of the cases where the tenant signed as producer the landlord signed as a consenting party, and there were probably requests that the benefit checks should

${ }^{2}$ Horseley v. Moss, 5 Tex. Civ. App. 341 (1893); Tignor v. Toney, 13 Tex. Civ. App. 518, 35 S. W. 88 I (1896); Fagan v. Vogt, 45 Tex. Civ. App. 240, 80 S. W. 664. (1904); Barnett v. Govan, 241 S. W. 276 (Tex. Civ. App., 1922).

According to the language of the Arkansas courts the cropper does not obtain title to his share of the crop until division, but prior to that time he has an "inchoate" interest in the crop equal to any balance due him. It is difficult to determine just what this "inchoate" interest amounts to for in most of the cases that have come before the courts it was shown that no balance was due the cropper. Ponder $v$. Rhea, 32 Ark. 435 (1877); Burgie v. Davis, 34 Ark. r79 (1879); Sentell v. Moore, 34 Ark. 687 (r879); Hendricks v. Smith, I2 S. W. 781 (Ark. I889); Bourland v. McKnight, 79 Ark. 427, 96 S. W. 179 (1906); Valentine v. Edwards, I12 Ark. 354, 166 S. W. 531 (1914); Barnhardt v. State, 169 Ark. 567, 275 S. W. 909 (1925). In any case if the cropper does not have title to his share of the crop he has a laborer's lien for the amount that may be due him. ARx. Dig. Stat. (Crawford \& Moses, 1921) \$6848; Burgie v. Davis, supra.

${ }^{25}$ Betts v. Ratliff, 50 Miss. 56r (1874); Doty v. Heth, 52 Miss. 530 (1876); Schliche v. Callicott, 76 Miss. 487, 24 So. 869 (1899); Staple Cotton Co-op Ass'n v. Hemphill, 142 Miss. 298, 107 So. 24 (1926). A statute gives the cropper a lien on the crop for his share or interest in it. Mtss. ConE ANN. (1930) $\$ 2238$.

${ }^{\infty}$ Al, . Code Ann., $\$ 8807$ (1928); Trapp v. First Nat. Bank, II7 So. I97 (1928); Heaton v. Slaten, I4I So. 267 (Ala., I932); Harris v. State, I 43 So. 242 (Ala., I932).

${ }^{27}$ GA. Code ANN. (Michic, 1926) $\$ \$ 3705,3334,3335,3339$ (1926); Fountain v. Fountain, $10 \mathrm{Ga}$. App. 758, 73 S. E. 1096 (1912); McElmurray v. Turner, 86 Ga. 215,12 S. E. 359 (1890).

${ }^{23}$ S. C. CODE (1932) \$8772; Peoples Bank v. Walker, 132 S. C. 254 , 128 S. E. 715 (1925).

${ }^{20}$ N. C. Code (Michie, 1931) \$2355; Tob. Growers' Co-op. Ass'n. v. Bissett, 187 N. C. I80, 121 S. E. 446 (1924); Rouse v. Wooten, 104 N. C. 229 , Io S. E. I90 (1889); Parker v. Brown, I36 N. C. 280,48 S. E. 657 (1904); White v. Riddle, 198 N. C. 511 , 152 S. E. 501 (1930). 
be made payable to them jointly. However, where the crop was worked by croppers and the landlord signed the contract, it was true in many cases and perhaps generally that the written consent of the croppers was not obtained. This was due to several reasons. Because of the advancing season it had been necessary to complete the sign-up campaign in as short a time as possible, and on some plantations there were a great many croppers. Although the cropper was legally a part owner or lienholder it was.not likely that in this connection he would be regarded as being on an equal footing with other persons interested in the crop, such as mortgagees or the landlord. This was particularly true in the black belt where most of the croppers were Negroes. Of course when the cropper was left off the contract he was not included on the benefit check, and when he signed as a consenting party his name did not appear except when the landlord was willing to request that it should.

The result was that most share-croppers and many third-and-fourth tenants received only such part of the benefit payments as their landlords chose to give them. Although croppers and tenants participated in the production of the crop and depended upon it for their compensation fully as much as their landlords did, there was no provision in the contract that they should receive any part of the benefit payments and no express obligation was put upon the party receiving the benefits to share them with any other person. The only direct statement on the subject is to be found in the instructions that went out to the field workers, which included the following sentence: "It is assumed that agreements by the operators and their tenants will provide for division of payments in proportion to their interest in the crop."

This assumption may have been justified in a majority of cases and we shall take for granted that most landlords treated their tenants fairly, but the way was left open for the unscrupulous landlord to take all the benefit at the expense of his tenants. He might simply refuse to pay his tenants any part of the benefit or he might misrepresent to them the amount he received from the government. In some cases his methods could be more subtle; he could credit his tenants on the books with a fair. share of the benefits and then wipe out this credit by making debits for alleged back debts or for usurious interest charges on living supplies furnished the tenants. Information is not available to indicate the extent to which these practices were engaged in, but the fact that little or nothing was done to prevent them, in spite of numerous complaints, renders the AAA subject to serious and justifiable criticism.

In any general appraisal of the 1933 program fairness requires us to remember that it was the first attempt in this country to control the production of any agricultural commodity. Also we must not forget that any plan for restricting the 1933 crop had necessarily to be executed in great haste. This being true, the program was remarkably successful in achieving its objective of acreage reduction. The goal had been the retirement of $10,000,000$ acres from production, and actually some 10,400,000 acres were taken out of production. However the program was not so successful in its larger purpose of reducing the cotton surplus. The plan had been adopted on the 
theory that a reduction in acreage would so restrict the size of the crop that the surplus of American cotton would be very materially reduced. But the r 933 season produced one of the highest yields per acre on record, and although the crop was reduced by approximately 4,400,000 bales, it amounted to some 13,200,000 bales as compared with $14,660,000$ bales which was the crop average for the years r928-r932. As a result it is estimated that the world carry-over for American cotton on August I, I934 will be in excess of 10,000,000 bales, which will be a reduction of only about I,000,000 bales from the carry-over of the previous year. There is no way of determining whether this result was due entirely to favorable climatic conditions or whether the more intensive cultivation of the acres left in production was an important element in the situation. Voluntary acreage reduction has not been proved to be an unsuccessful method of controlling cotton production, but the passage of the Bankhead Cotton Control Bill. ${ }^{30}$ indicates that Congress and a majority of the cotton growers are not willing to rely upon it as the sole means of accomplishing that end.

It cannot be denied that the I933 program greatly increased the income of cotton growers as a whole. Estimates indicate that receipts from the 1933 crop plus the benefit payments were more than double the income obtained from the crop of 1932. The most severe criticism to be made of the program concerns the manner in which the benefits were distributed. Both landlords and tenants were asked to participate in the 1933 program and each took part by contributing his interest in the crop that was plowed under. Tenants as well as landlords had a right to assume that the government would see that they were fairly compensated for their property which was thus destroyed. The contract should have been drawn so that the benefit payments would have been made directly to landlords and tenants in proportion to their respective interests in the crop. In the absence of such a provision the least that should have been done was to provide that the party signing as producer was under a contractual obligation to the Secretary to share the benefit payments with any other persons who might be interested in the crop as landlords or tenants. ${ }^{31}$ The absence of such provisions has resulted in a very unfair distribution of the benefit payments in many cases. ${ }^{81^{*}}$

IV

With the carry-over of American cotton promising to exceed ro,000,000 bales on August I, I934 it was clear that the restriction of cotton production would have to be

Described in Cavers, Production Control by Taxation, infra, p. 349.

a Compare the requirements in the flue-cured tobacco adjustment contracts that where more than one person is interested in the crop payment should be made to a trustee designated by the interested parties. The trustee may, however, be the landlord. See Knapp and Paramore, Flue-Cured Tobacco Developmenes wnder the $A A A$, infra at $\mathrm{p} .342$.

12 The landlord and tenant problems of the cotton program were reviewed in a report in the spring of this year by Mr: Calvin Bryce Hoover, Economic Adviser to the Secretary. A press release dated May 9, 1934, announced the appointment of eight district agents from the Extension Service to serve as field men "to investigate and adjust all complaints, violations, and misunderstandings under cotton adjustment contracts." The release did not state what complaints were to be considered nor how they were to be adjusted. 
continued through the season of 1934 and probably that of 1935 . To accomplish this, plans were made for the two-year period calling for a reduction in acreage based upon the average acreage planted to cotton during the years I928-1932. It was planned that the reduction should be 40 per cent in 1934 and 25 per cent in 1935 . This meant that approximately $15,000,000$ acres would be eliminated from cultivation in 1934, a considerably more drastic reduction than that accomplished in 1933 .

Since arrangement was made for the sign-up to take place before the planting of the 1934 crop, it was possible to draw the contract in considerably different form from that used in r933. It is contained in one document and provides that in 1934 the party signing as producer "rents" to the Secretary a specified number of acres which may be from 35 to 45 per cent of the average acreage in the farm which was planted to cotton during the years I928-1932. This I928-I932 average is called the base acreage, and for the year 1935 the producer rents that number of acres which the Secretary shall prescribe, which number is not to exceed 25 per cent of the base acreage. The "rented acres" are to represent in productivity a fair average of the cotton land on the farm, and the producer agrees to use them only for "soil-improving crops; erosion-preventing crops; food crops for consumption by the producer on this farm; feed crops for the production of livestock or livestock products for consumption or use by the producer on this farm; or fallowing; such other uses as may be permitted by the Secretary or his authorized agent."32

As consideration for the performance by the producer the Secretary agrees to make benefit payments of two different kinds, called the rental payment and the parity payment. The rental payment is fixed at $3^{1 / 2}$ cents per pound on the average yield of lint cotton per acre for the farm in the years $1928-1932 .{ }^{33}$ This payment, which is not to exceed $\$ 18$ per acre, is made to the producer in two instalments; the first in the spring of 1934 in order to eliminate as far as possible the demand for production credit, and the second about picking time (August and September) in order to help meet the needs for ready cash at that time. The parity payment, which is to be made to the producer between December I, I934, and January I, I935, will be not less (and probably little more) than I cent per pound on the "farm allotment," which is defined as $4^{\circ}$ per cent of the average yield of the farm during the years 1928-1932. In case any part of the farm is worked by share-tenants or share-croppers the producer agrees to pay them a portion of the parity payment based upon their share of the crop. This payment need not be in cash but may be made in "supplies or other benefits."

The effect of these provisions with respect to the distribution of benefits between landlords and tenants can be made clearer by applying them to a specific situation. Let us take first the common case of a share-cropper who is likely to be working

\footnotetext{
${ }^{22}$ Like the 1933 contract the 1934 and 1935 contract had to be approved by a local committec and 2 county committee and did not become binding until accepted by the Secretary.

${ }^{83}$ The producer was required to furnish the necessary information concerning the number of acres planted to cotton and the yield per acre during the years 1928-1932.
} 
about 15 acres of land, which we shall treat as the farm. We shall assume that the whole 15 acres was planted in cotton during the years 1928-1932, and therefore the base acreage is 15 . The landlord signs a 1934 and 1935 contract in which he "rents" 40 per cent of his base acreage or 6 acres to the Secretary. We shall assume that the average yield of the land during the I928-1932 period was I75 pounds of lint cotton per acre; consequently the rental payment will amount to $\$ 6.125$ per acre or a total of \$36.75. Since the average annual production of the farm for the -year 1928-1932 was 2625 pounds of lint cotton, the farm allotment will be $4^{\circ}$ per cent of this or ro5o pounds. The parity payment, computed on the basis of I cent per pound on the farm allotment, will amount to $\$ 10.50$. Since the cropper is entitled to one-half of the crop the landlord is obligated to pay him one half of the parity payment in cash, "supplies," or "other benefits." Thus the cropper's total share of the benefit payments will amount to $\$ 5.25$ and the landlord's to $\$ 42.00$.

It is interesting to compare the total income received by landlord and cropper in cases where the landlord signs a contract with that received by them in cases where the landlord refuses to enter into the acreage reduction program. Let us assume the facts of the case given above and that the land in 1934 yielded 175 pounds per acre which could be marketed for ro cents a pound. If no contract were signed and all of the 15 acres were planted in cotton, the landlord and cropper would each receive a gross return of $\$ 131.25 .{ }^{34}$ If a contract were entered into, the landlord's gross income would be $\$ 120.75$ and the cropper's $\$ 84.00$. The disparity in net income would be even greater, for the reduction in acreage reduces the landlord's costs but not the cropper's. $^{35}$ Under the 1934 and 1935 contract the landlord has everything to gain and the cropper everything to lose.

The position of the third-and-fourth renter may be even worse than that of the cropper. Unlike the 1933 contract, the 1934 and 1935 contract makes no provision for consenting parties; a person enters into it as principal party or not at all. According to the terms of the contract there are three classes of persons who may sign as principal party or producer: "owners," "cash renters" and "managing share-tenants." By administrative ruling the following rule has been formulated to govern the eligibility of persons to sign the contract: "Any producer who is an owner, landlord, cash tenant, or managing share-tenant and who operates or controls a cotton farm may be a party to a 1934 and 1935 cotton acreage reduction contract covering such farm. ..." The difficulty in applying this rule arises out of the vagueness of the term "managing share-tenant," for there is no class of tenants in the South recognized as such. A footnote to the contract defines this unknown species of tenant as

\footnotetext{
" This hypothetical case disregards the cffect of the Bankhead Act taxing the ginning of cotton grown by non-coöperating producers.

${ }^{25}$ It has been argued that this result is justified because a reduction in acreage does $\left.n \cdot\right)^{\prime}$ reduce the landlord's capital investment in his land or his important fixed charges such as taxes, while it does reduce substantially the amount of labor required of the cropper. But it must be remembered that in most cases the cropper will not be able to spend his spare time in gainful employment, and therefore the gift of leisure to him is not equivalent to pecuniary compensation.
} 
follows: "A managing share-tenant is a share-tenant who furnishes the work-stock, equipment, and labor used in the production of cotton and who manages the operation of this farm." This excludes the cropper and includes all third-and-fourth renters unless they are excluded by the phrase "who manages the operation of the farm." When does a third-and-fourth renter "manage the operation" of the farm? The answer to the question depends upon a myriad of circumstances which are different in every case-such as whether the landlord lives on the farm, whether cotton farming is his principal occupation, whether he has confidence in the tenant, and whether the tenant has been with him for a period of years. And in any case, whatever the circumstances may have been in the past, if the landlord asserts that in the future he will manage the operation of the farm, who can claim that the third-and-fourth renter is still a "managing share-tenant"? The AAA has consistently refused to issue a more specific definition of the term, with the result that the opportunity of a third-and-fourth renter to sign as a "managing share-tenant" has depended in part upon the attitude of the county agent and principally upon the willingness of the landlord to share benefit payments with him. In some counties no third-and-fourth renters were permitted to qualify as signers while in others some were. On the whole it is to be expected that an examination of the records would show comparatively few "managing share-tenants."

The result of this situation becomes graphic if we trace its effect upon the distribution of benefits. Let us take the facts of the illustration given above and assume that the land, instead of being worked by a share-cropper, is cultivated by a thirdand-fourth renter who is not permitted to sign as a "managing share-tenant." The distribution of benefits will be the same except that the renter will be entitled to three-fourths of the parity payment instead of one-half. This means he will receive as total benefits $\$ 7.87$, while his landlord will get $\$ 39.38$. If no contract is signed and the crop is sold for ro cents a pound the renter's gross income will be $\$ 196.87$ and the landlord's will amount to $\$ 65.62 . .^{36}$ If a contract is entered into by the landlord and the renter is not permitted to sign, the renter's total gross return will be reduced to $\$ 125.99$ and the landlord's raised to $\$ 78.75$-an even more unfair division than that made in the case of the cropper.

The contract provides that if the farm is operated by a "managing share-tenant" the tenant shall sign the contract with the landlord and the rental payments shall be made one-half to the landlord and one-half to the tenant. The parity payment is to be divided between the parties according to their respective interests in the crop. This means that if the landlord permits his renter to sign as a "managing sharetenant" his own benefits will be substantially reduced. In the above illustration the reduction would be from $\$ 39.38$ to $\$ 21.00$. This is sufficient, particularly where there

\footnotetext{
${ }^{2}$ See note 34, supra.
} 
are a number of third-and-fourth renters on a farm, to induce most landlords to "manage the operation" of their farms. ${ }^{37}$

One of the most serious problems of the 1934 and 1935 program is the likelihood that producers will effect their acreage reduction by dismissing a portion of their tenants, thus swelling the landless-tenant class which has already grown to distressing proportions in the South. ${ }^{35}$ In an attempt to prevent this from happening, a clause was inserted in the contract providing that producers shall "endeavor in good faith to bring about the reduction of acreage contemplated in this contract in such manner as to cause the least possible amount of labor, economic, and social disturbance, and to this end, insofar as possible, he shall effect the acreage reduction as nearly ratably as practicable among tenants on this farm; shall, insofar as possible, maintain on this farm the normal number of tenants and other employees; shall permit all tenants to continue in the occupancy of their houses on this farm, rent free, for the years 1934 and 1935 , respectively (unless any such tenant shall so conduct himself as to become a nuisance or a menace to the welfare of the producer); during such years shall afford such tenants or employees, without cost, access for fucl to such woods land belonging to this farm as he may designate; shall permit such tenants the use of an adequate portion of the rented acres to grow food and feed crops for home consumption and for pasturage for domestically used livestock; and for such use of the rented acres shall permit the reasonable use of work animals and equipment in exchange for labor." A provision more hedged about by qualifying language could hardly have been drafted. It is not easy to imagine a more difficult case to prove than that a producer has not "endeavored in good faith" to bring about "insofar as possible" a reduction in acreage "as ratably as practicable among his tenants." With no stronger obligation imposed upon them to keep their tenants than that contained in this section, it is to be expected that many landlords will reduce their acreage in the easiest and most economical manner, and that the burden of southern relief agencies will continue to grow.

It is too early to estimate the general effect of the 1934 program, but there is every reason to believe that, fortified by the Bankhead Act, it will bring about the desired reduction in acreage and restriction of the 1934 crop. With the cotton surplus further reduced, it is to be expected that the increased price of cotton, plus the benefit payments, will bring to cotton producers as a group the best return they have obtained in some years. But whether there will be an increase in the purchasing power of the masses engaged in cotton agriculture is a very different story. If we are not to be irrational optimists we must not be surprised to find that the inequitable distribution of benefits and the radical reduction in the number of tenants needed in cotton

${ }^{37}$ The contract should have provided specifically for a payment of a stated proportion of the benefits to each of the persons furnishing the land, the teams and cquipment, and the labor. This division of the payments would not have depended upon which party signed the contrat and would have provided a workable rule in each case.

${ }^{34}$ Sce Blackwcil, Rural Relief in the South: FERA's Problem in Eastern North Curolina, infra. 
production will result in a definite lowering of the economic status of a large portion of the southern agricultural population. For the immediate future the government must be prepared to supply federal relief to the tenants whose means of sustenance has been destroyed or reduced by the government's own program. Any satisfactory solution of the problem can only be brought about by a long-range program designed to take surplus labor as well as surplus land out of cotton production. Such an ment is willing to recognize the problem of agricultural labor as an integral part of agricultural adjustment, no general and permanent improvement in the economic undertaking would of course be a difficult and complicated one, but until the governcondition of the farming population of the South can be achieved. 